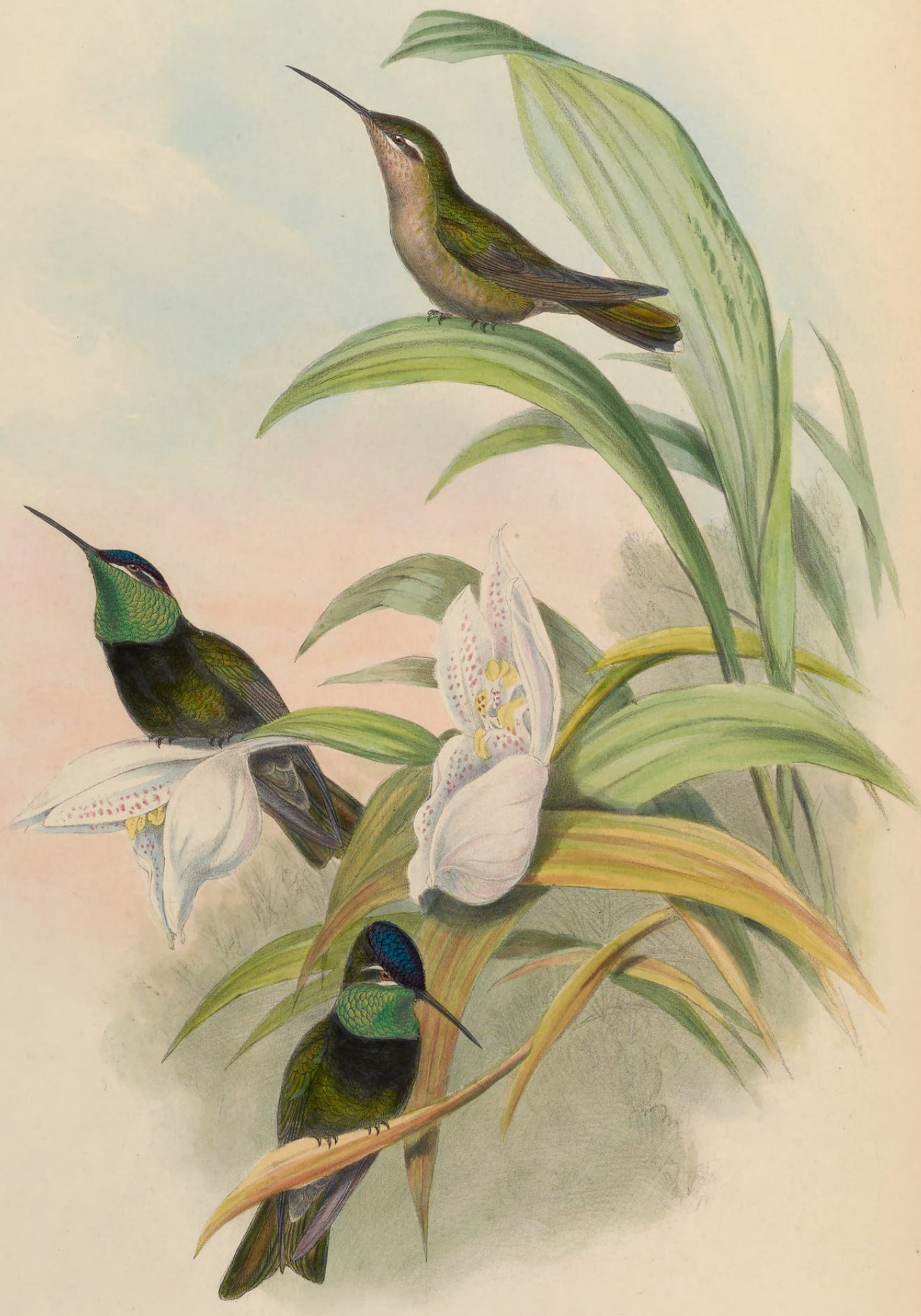

EUGENES FULGENS. 


\title{
EUGENES FULGENS.
}

\author{
The Rivoli.
}

Trochilus fulgens, Swains. in Phil. Mag. 1827, p. 441.

Ornismya Rivolii, Less. Hist. Nat. des Ois. Mou., p. 48. pl. 4.

Trochilus Rivolii, Jard. Nat. Lib. Humming Birds, vol. ii. p. 96. pl. 18.

Mellisuga fulgens, Gray and Mitch. Gen. of Birds, vol. i. p. 112, Mellisuga, sp. 2.

Delattria fulgens, Bonap. Consp. Gen. Av., p. 70, Delattria, sp. 4.

Coligena fulgens, Bonap. Rev. et Mag. de Zool. 1854, p. 252.

Coeligena fulgens, Reichenb. Aufz. der Colibris, p. 7.-Ib. Troch. enumer., p. 3. pl. DcLxxxvi. figs. 4513,4514 .

THIs well-known Mexican species, so celebrated for the beauty of its colouring, and the bold style of its markings, enjoys a very wide range of habitat, extending from the latitude of Jalapa in Mexico to the city of Guatemala; but only frequents high table-lands, such as those of Jalapa and Temiscaltepec. This fine bird was described by Swainson under the specific appellation of fulgens some years prior to that of Rivoli assigned to it by M. Lesson, in honour of M. Massena, Prince of Essling and Duke of Rivoli.

It is to be regretted that nothing has yet been recorded respecting its habits and economy, or the particular plants among which it seeks its food.

In its general contour and in some of its markings it bears a close resemblance to the members of the genus Oreotrochilus, but the straighter and more lengthened form of its bill prevents me from placing it in that group.

The sexes, as is usual with many other groups of Humming Birds, offer a very decided difference in their colouring, the female being entirely destitute of the lovely hues which adorn the head and throat of the male.

Fine examples of this species, collected by M. Rivera Paz, have been forwarded to me by Mr. Skinner.

The male has the forehead and crown of a rich violet-blue; chin, throat, and sides of the neck, luminous grass-green; all the upper surface, wing-coverts, breast, and abdomen bronzy green; the back of the neck and breast appearing black when viewed in front; wings purplish brown; two central tail-feathers bronzy green, the remainder brownish bronze, with a wash of bronzy green at the base and at the tip; under tailcoverts olive-grey, fringed with greyish white.

In the young male the forehead is grey, with a few brilliant bluish-green feathers appearing on the crown; upper surface and wing-coverts as in the adult; wings purplish brown; tail darker, and the lateral feathers crossed with a broad mark of dark brown and tipped with grey; under surface greyish brown, with a few of the bright grass-green feathers on the throat.

In the female the crown of the head is brown; upper surface, wings, and tail as in the young male, but the lateral tail-feathers more largely tipped with greyish white; all the under surface greyish brown, washed with green on the flanks, and with the centre of the throat-feathers tinged with reddish; before the eye, but below the lores, a small patch of white, and behind the eye another white mark curving down posterior to the ear-coverts.

The figures and plant are of the natural size; the latter is the Anguloa unifora. 


\section{$2 \mathrm{BHL}$ Biodiversity Heritage Library}

Gould, John. 1852. "Eugenes fulgens, The Rivoli. [PI. 59]." A monograph of the Trochilidae, or family of humming-birds 2, https://doi.org/10.5962/p.316868.

View This Item Online: https://www.biodiversitylibrary.org/item/108332

DOI: https://doi.org/10.5962/p.316868

Permalink: https://www.biodiversitylibrary.org/partpdf/316868

\section{Holding Institution}

Smithsonian Libraries

\section{Sponsored by}

Smithsonian Institution Libraries

\section{Copyright \& Reuse}

Copyright Status: NOT_IN_COPYRIGHT

This document was created from content at the Biodiversity Heritage Library, the world's largest open access digital library for biodiversity literature and archives. Visit BHL at https://www.biodiversitylibrary.org. 